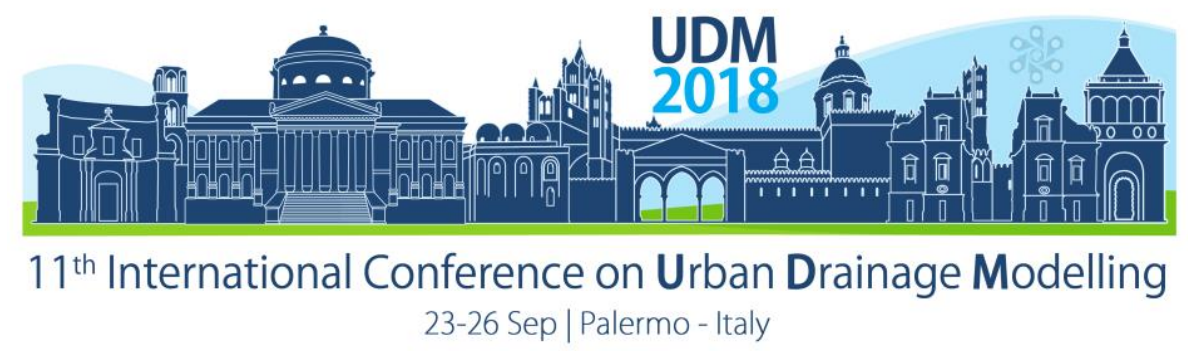

\title{
An assessment of per capita water consumption in Sirte, Libya
}

\author{
Iman Alharsha ${ }^{1}$, Fayyaz Memon ${ }^{1}$, Raziyeh Farmani ${ }^{1}$ \\ 1 Centre for Water Systems, University of Exeter, Exeter, Devon EX4 4QF, UK \\ iasa202@exeter.ac.uk
}

\begin{abstract}
Worldwide, where freshwater resources are limited, a major water scarcity problem occurs. Population growth, which leads to increased water consumption with high inefficiencies of household water use behaviour especially in developing countries, makes the problem worse. In this situation, a sustainable urban water management approach which considers household water consumption patterns is required. However, country specific water consumption data particularly for the developing countries is limited. This paper investigates per capita water consumption in Sirte city by evaluating the indoor and outdoor domestic water uses using a survey. The survey contains information about demographic, socio-economic and household water end use behavioural characteristics. The preliminary results suggest that water consumption varies with the type of dwelling and females tends to consume considerable more water in comparison to males. Household income does not seem to affect water consumption.
\end{abstract}

Keywords: Domestic water end-uses, Household Water consumption, Survey

\section{INTRODUCTION}

Water is considered as one of the principle needs of all living organisms. Human needs water in all his life activities. These include daily life practices (domestic needs), industrial and agricultural activities. In many countries water demands are continuously increasing due to population growth, urbanization and improved living standards (Domene et al. 2006; Kenney el at. 2008 and Lee el at. 2012). On the other hand, limited water resources and climate uncertainties magnify the water scarcity problem. Arnell (2004) reported that two-thirds of the world's population would be living in water stressed countries by 2025 . The gap between demand and availability of water resources is reaching critical levels in many countries in the world. Water demand management measures such as water reuse require detailed knowledge of water end-use behaviours and household's water use patterns to ensure efficient water resources management planning. In developed courtiers domestic water demand has been effectively analysed, but this is not the case in the developing countries (Nauges and Whittington 2009). Several studies have analysed end-use water consumption characteristics. In Australia, studies were done on water end-uses characteristics in terms of seasonal water consumption variability, frequency, duration, flow rate, peak demands and demand patterns (Loh and Coghlan 2003; Willis el at 2013; Beal 2013). A study by Wa'el et al. (2016), evaluated the influence of various household characteristics on per capita consumption patterns currently prevailing in urban areas of Duhok city, Iraq. This paper presents the result of a survey of 230 households in Sirte city, Libya which contains information about demographic, socio-economic and household water consumption characteristics of the participants.

\section{MATERIALS AND METHODS}

\subsection{Study Area}

The city of Sirte, is located in the north of Libya between $31^{\circ} 12^{\prime} 32.11^{\prime \prime}$ North and $16^{\circ} 35^{\prime}$ 19.18' East (Figure 1). It has a population of around 70,000 inhabitants (MHU). Its climate is classified as arid affected by the Mediterranean Sea in the north and the desert in the south. 


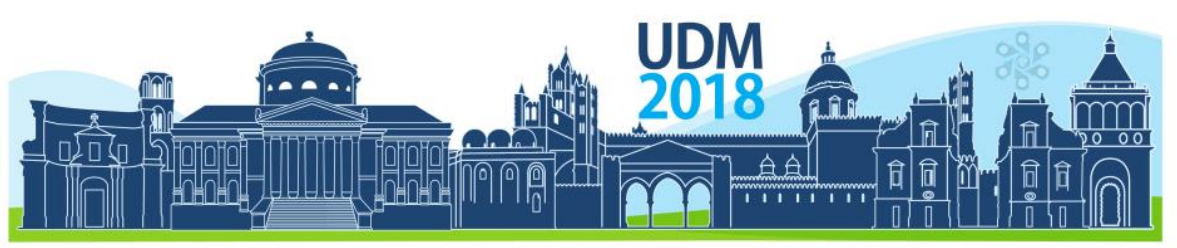

$11^{\text {th }}$ International Conference on Urban Drainage Modelling

23-26 Sep | Palermo - Italy

The rainy season in Sirte starts in September and lasts till March. The highest amount of rainfall is normally in January, while during July there are no rains. Water source for the city is from Man-Made River Project (MMRP).Water is supplied to households in Sirte city every day for 24 hours. However, some areas outside the city are sometimes supplied 3 to 4 times a week. Therefore, people outside the city store water in underground and overhead tanks and use it for different activities. Because of uncertainties due to power cuts even in the city, houses have storage facilities.
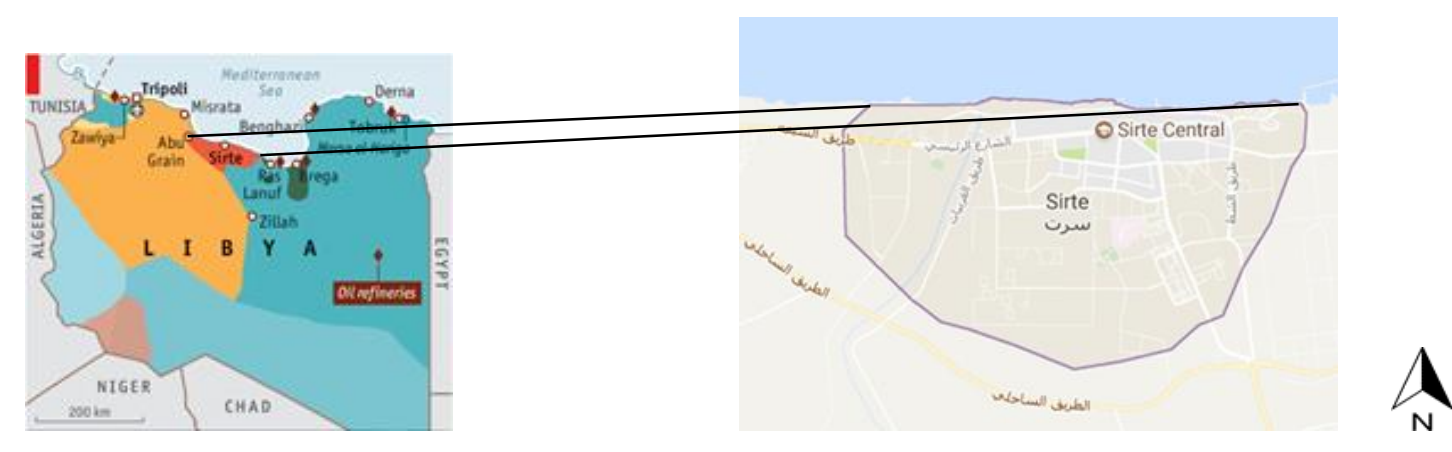

Figure 1. Location of Sirte city, Libya (Latitude.to 2017)

\subsection{Data collection}

In this study, data on household characteristics were collected using a comprehensive questionnaire survey. The questionnaires, each with about 67 multiple choice questions, were prepared in both English and Arabic language. Questions were on household and water enduse characteristics. The household characteristics questions included information on: number of people in the household (children, elders, adult males and females) and thier ages, household type, number of rooms, number of kitchens and toilets, number of floors, total builtup area, garden area and total montly income. On water end-use side, questions were on the frequencey, flow rate and duration of use of bath, shower, hand wash basin, toilet flushing, dishwashing, clothes swashing (manually or using machine), rooms, kitchens and toilets floor washing, garden watering, vehicle washing and swimming pool. For the winter season December 2017, the quesitionnaires were distributed to student at Sirte University in Libya as household representatives. Over 400 questionnaires were distributed and 230 replies were received. The data for the 230 questionnaires was transfered and analysed using IBM SPSS Statistics Version 24 package. The analysis included estimation of statistical parameters (i.e., avarage, minimum, maximum and distribuation shape identification through kurtosis and skewness) for the characteristics of the 230 households.

\section{RESULTS AND DISCUSSION}

\subsection{Household characteristics}

The analysis of household characteristics in the study area was based on 230 respondents as shown in Table 1. The analysis shows that the average number of people in a household is 6.84. In addition, the average number of children, adult males and females is 1.81, 2.11 and 2.48 respectively. The average number of elders above 65 years is 0.40 . The percentage of houses is $77.83 \%$ and $22.17 \%$ is apartments. Moreover, the total built up area for a house or apartment ranged between 100 and $650 \mathrm{~m}^{2}$ with about $35.23 \mathrm{~m}^{2}$ garden area, the minimum 


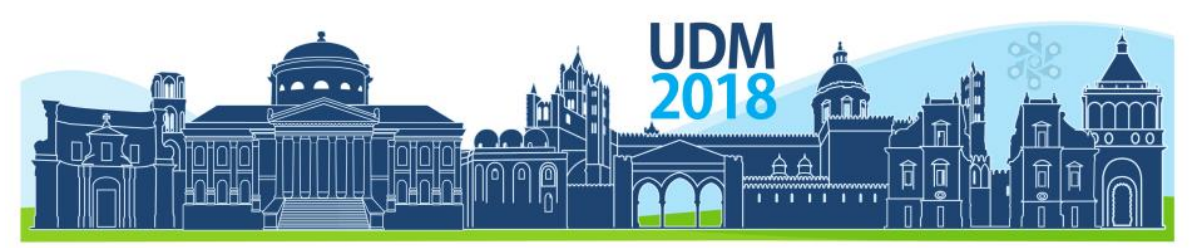

$11^{\text {th }}$ International Conference on Urban Drainage Modelling

23-26 Sep | Palermo - Italy

and maximum number of floors are 1 and 3 respectively. The average number of kitchens, toilets and rooms in a household are 1.52, 2.59 and 6.24 respectively. The average monthly household income is 368.92 LD ( $£ 1.888=1$ LYD).

Table 1. Summary of household characteristics in Sirte, Libya

\begin{tabular}{|c|c|c|c|c|c|c|c|c|}
\hline $\begin{array}{l}\text { Household } \\
\text { characteristics }\end{array}$ & Min. & Max. & Mean & Median & $\begin{array}{c}\text { Std. } \\
\text { Deviation }\end{array}$ & Skewnsess & Kutosis & $\begin{array}{c}\text { Confidence } \\
\text { interval } \\
(95 \%)\end{array}$ \\
\hline $\begin{array}{l}\text { No. of People in } \\
\text { household }\end{array}$ & 1.00 & 19.00 & 6.84 & 6.50 & 2.84 & 0.929 & 1.55 & 0.05 \\
\hline $\begin{array}{l}\text { No. of children } \\
\text { (<15 years) }\end{array}$ & 0.00 & 6.00 & 1.81 & 2.00 & 1.77 & 0.460 & -1.09 & 0.13 \\
\hline $\begin{array}{l}\text { No. of adult males } \\
\text { (15-65 years) }\end{array}$ & 0.00 & 7.00 & 2.11 & 2.00 & 1.49 & 0.837 & 0.08 & 0.09 \\
\hline $\begin{array}{l}\text { No. of adult females } \\
\text { (15-65 year) }\end{array}$ & 0.00 & 9 & 2.48 & 2.00 & 1.66 & 1.04 & 1.07 & 0.09 \\
\hline $\begin{array}{l}\text { Number of adult } \\
(>65)\end{array}$ & 0.00 & 2.00 & 0.40 & 0.00 & 0.645 & 1.35 & 0.590 & 0.21 \\
\hline $\begin{array}{l}\text { Total built-up area } \\
\mathrm{m}^{2} \text { of all floors }\end{array}$ & 100 & 650 & 231.45 & 190 & 91.22 & 1.33 & 1.88 & 0.05 \\
\hline $\begin{array}{l}\text { Number of kitchens } \\
\text { in the household }\end{array}$ & 1.00 & 5.00 & 1.52 & 1.00 & 0.73 & 1.43 & 2.24 & 0.06 \\
\hline $\begin{array}{l}\text { Number of toilets } \\
\text { in the household }\end{array}$ & 1.00 & 6.00 & 2.59 & 2.00 & 1.05 & 1.03 & 0.44 & 0.05 \\
\hline $\begin{array}{l}\text { Number of rooms } \\
\text { in the household }\end{array}$ & 2.00 & 11.0 & 6.24 & 5.00 & 2.21 & 0.92 & -0.16 & 0.05 \\
\hline $\begin{array}{l}\text { Number of floors } \\
\text { In the household }\end{array}$ & 1.00 & 3.00 & 1.26 & 1.00 & 0.485 & 1.69 & 1.98 & 0.05 \\
\hline $\begin{array}{l}\text { Garden area in } \mathrm{m}^{2} \\
\text { in the household }\end{array}$ & 0.00 & 550 & 35.23 & 3.75 & 69.37 & 4.21 & 22.85 & 0.26 \\
\hline $\begin{array}{l}\text { Monthly family } \\
\text { income/household } \\
\text { (LYD, Libyan Dinar } \\
\text { per month) }\end{array}$ & 50.0 & 2500 & 368.92 & 300.0 & 280.12 & 3.03 & 15.91 & 0.10 \\
\hline Household type & \multicolumn{4}{|c|}{ Houses $77.83 \%$} & \multicolumn{4}{|c|}{ Apartments $22.17 \%$} \\
\hline
\end{tabular}




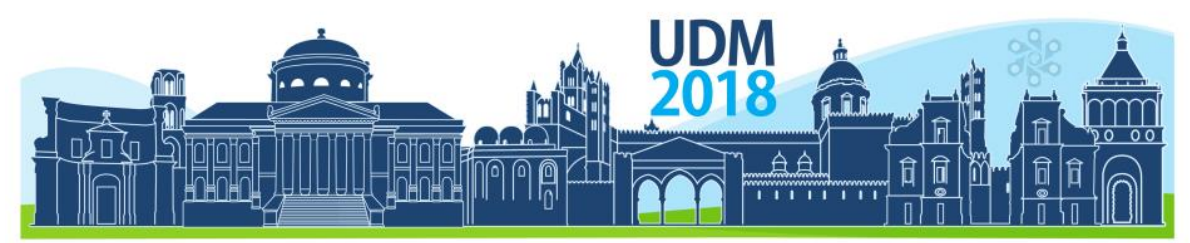

$11^{\text {th }}$ International Conference on Urban Drainage Modelling

23-26 Sep | Palermo - Italy

\subsection{Average per Capita Water end-use}

The average water consumption per capita was divided into end-uses which included bath, showering, hand wash basin, toilet flushing, dishwashing, laundry, house washing, garden watering, cooking, vehicle washing and swimming pool. The daily per capita water use for all activities are the function of the frequency, the duration and the flow rate. The average water consumption volumes and percentages for these end uses are shown in Figures 2 and 3 respectively. These values were obtained through questionnaire survey for households in the study area. The sum of the all the end-uses water consumption gives the average water consumption per capita in Sirte Libya as $354 \mathrm{l} / \mathrm{p} / \mathrm{d}$.

There are differences in average water consumptions with respect to type of house and gender. For instance, the average water consumption for apartments and houses is $329 \mathrm{l} / \mathrm{p} / \mathrm{d}$ and $362 \mathrm{l} / \mathrm{p} / \mathrm{d}$ receptively. While on average, females and males consume $369 \mathrm{l} / \mathrm{p} / \mathrm{d}$ and 337 $\mathrm{l} / \mathrm{p} / \mathrm{d}$ receptively. The result shows that females consumed more water than male because they stay most of the time at home.

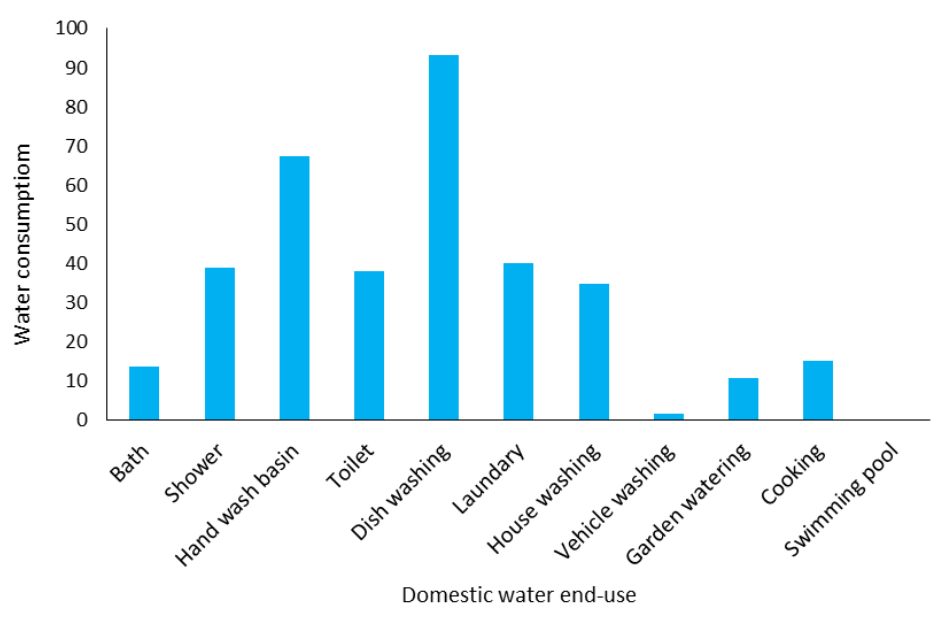

Figure2. Daily per capita average water consumption (l/p/d)

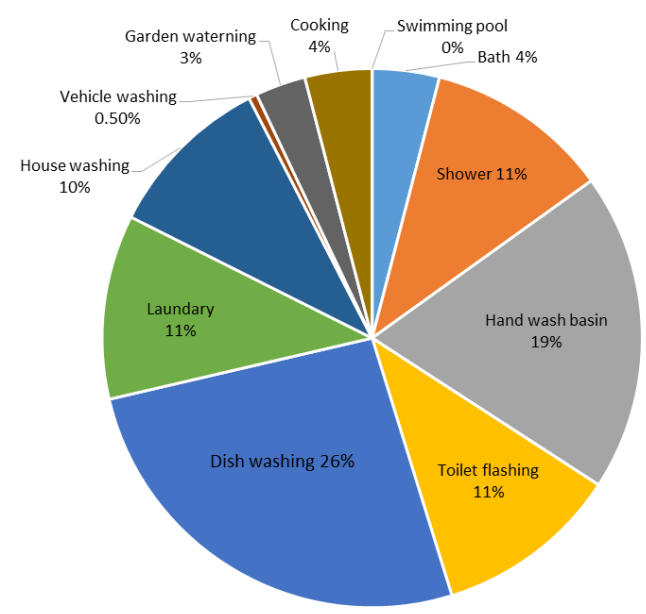

Figure 3. Percentage of enu-use water consumption 


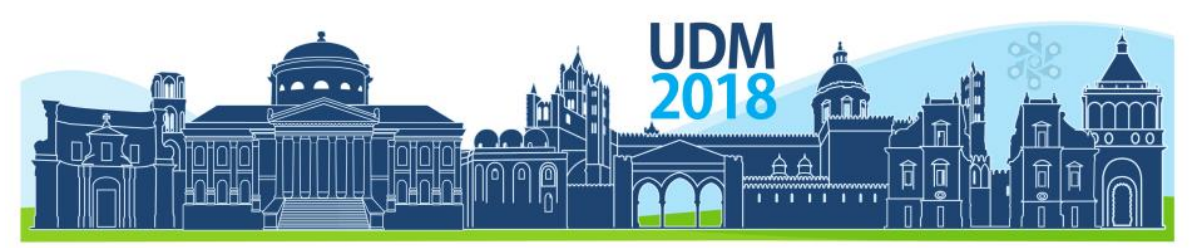

$11^{\text {th }}$ International Conference on Urban Drainage Modelling

23-26 Sep | Palermo - Italy

\subsection{Water user behaviour}

The water user behaviour was captured by recording the frequency and duration of use of different appliances. The results are summarised as below in Table 2.

Table 2. Summary of water user behaviour statistics

\begin{tabular}{|c|c|c|c|c|c|c|}
\hline \multirow{2}{*}{ Activity/appliance usage } & \multicolumn{3}{|c|}{ Frequency (person/day) } & \multicolumn{3}{|c|}{ Duration (minutes/person/day) } \\
\hline & Mean & Min-Max. & $\begin{array}{l}\text { Standard } \\
\text { Deviation }\end{array}$ & Mean & Min-Max. & $\begin{array}{l}\text { Standard } \\
\text { Deviation }\end{array}$ \\
\hline Bath & $0.08^{`}$ & $0.00-0.57$ & 0.132 & - & - & - \\
\hline Shower & 0.64 & $0.14-2.00$ & 0.335 & 19.00 & $2.00-55.0$ & 11.67 \\
\hline Hand wash basin & 5.97 & $2.0-18.0$ & 2.12 & 5.25 & $3.00-10.0$ & 1.12 \\
\hline Toilet flushing & 5.00 & $2.0-10.0$ & 1.67 & - & - & - \\
\hline Cooking & 1.62 & $1.0-3.0$ & 0.546 & - & - & - \\
\hline Dish washing (manually) & 3.20 & $0.0-6.00$ & 1.41 & 8.80 & $0.0-27.50$ & 4.24 \\
\hline Dish washing (machine) & 0.35 & $0.0-3.0$ & 0.745 & - & - & - \\
\hline Laundry (manually) & 0.08 & $0.0-0.86$ & 0.162 & 2.69 & $0.0-50.0$ & 6.24 \\
\hline Laundry (machine) & 0.63 & $0.0-1.43$ & 0.290 & - & - & - \\
\hline Toilet washing & 1.66 & $1.0-4.0$ & 0.814 & 5.75 & $2.0-20.0$ & 2.65 \\
\hline Kitchen washing & 0.25 & $0.14-0.57$ & 0.122 & 6.37 & $2.0-18.0$ & 2.51 \\
\hline Rooms washing & 0.186 & $0.0-0.57$ & 0.11 & 13.0 & $0.0-37.5$ & 6.60 \\
\hline Vehicle washing & 0.05 & $0.0-0.29$ & 0.08 & 6.39 & $0.0-45.0$ & 11.21 \\
\hline Garden watering & 0.130 & $0.0-0.86$ & 0.172 & 11.96 & $0.0-87.5$ & 17.90 \\
\hline
\end{tabular}

Table 2 shows that the most frequently used appliance is hand wash basin which is used approximatly 6 times a day. People wash their hands during praying times and after toilets. However, vehicle washinig was the lowest frequency activity which is 0.05 per capita per day. This is because people perfer washing thier vehicle in garages. The second lowest activity is bathing which is 0.08 per capita per day. Although each appartment and house in Sirte city has a bath, people use it as shower in most cases with respect to duration of water consumption end-use, the shower has the highest duration which is 19 minutes. The duration for manual laundary was the lowest at around 3 minutes.

\subsection{Impact of Household Characteristics on the Total Average Water Consumption (I/hh/day)}

The analysis of impact of the household water consumption shows that there is a strong positive relationship between the number of people in the household and total water 


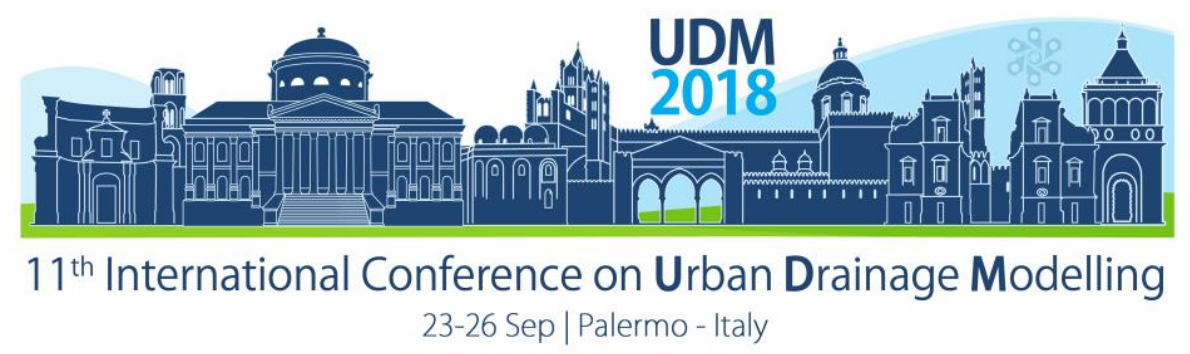

consumption. The Pearson correlation coefficient (PCC) is 0.77 . The correlation between builtup area and total water consumption $(P C C=0.42)$ is moderate. The data shows very weak correlation of consumption with the family income and garden area which is 0.21 and 0.1 respectively. This means the total household income does not seem to affect the water consumption because water is free. On the other hand, some people in Sirte do not water their gardens in winter.

The collected data is planned to be used to reduce wastewater generation profiles. These are planned to be used as an input to simulate the effects of water consumption on the drainage network for the city of Sirte

\section{CONCLUSIONS}

In this study, the household characteristics and average domestic water consumption of Sirte, Libya was analysed and determined using a questionnaire survey. IBN SPSS Statistics Version 24 package was used for data analysis. The analyses were split into household enduse types. From which, the average water consumption was found to be $354 \mathrm{l} / \mathrm{p} / \mathrm{d}$. The results showed that there is a strong and moderate impact on total household water consumption by family size and built-up area respectively. However, total family income and garden area have low influence on total household water consumption.

\section{ACKNOWLEDGEMENT}

The funding for this research has been provided by the Ministry of Higher Education and Scientific Research in Libya and is thankfully acknowledged.

\section{REFERENCES}

Arnell, N. W. (2004). Climate change and global water resources: SRES emissions and socio-economic scenarios. Global environmental change, 14(1), 31-52.

Beal, C. D., Stewart, R. A., \& Fielding, K. (2013). A novel mixed method smart metering approach to reconciling differences between perceived and actual residential end use water consumption. Journal of Cleaner Production, 60, 116-128.

Domene, E., \& Saurí, D. (2006). Urbanisation and water consumption: Influencing factors in the metropolitan region of Barcelona. Urban Studies, 43(9), 1605-1623.

Kenney, D. S., Goemans, C., Klein, R., Lowrey, J., \& Reidy, K. (2008). Residential water demand management: lessons from Aurora, Colorado. JAWRA Journal of the American Water Resources Association, 44(1), 192207.

Latitude.to 2017. Available from: http://latitude.to/map/ly/libya/cities/sirte (Accessed 03/11/2017)

Lee, D. J., Park, N. S., \& Jeong, W. (2012). End-use analysis of household water by metering: the case study in Korea. Water and Environment Journal, 26(4), 455-464.

Loh, M., \& Coghlan, P. (2003). Domestic water use study in Perth, Western Australia, 1998-2001. Perth: Water Corporation.

MHU. The Ministry of Housing and Utilities, Tripoli, Libya. Unpublished report.

Nauges, C., \& Van Den Berg, C. (2009). Perception of health risk and averting behavior: An analysis of household water consumption in Southwest Sri Lanka.

The world's Trusted currency Authority (2018), Available from:

https://www.xe.com/currencyconverter/convert/?Amount=1\&From=GBP\&To=LYD (Accessed 09/04/2018)

Wa'el A, H., Memon, F. A., \& Savic, D. A. (2016). Assessing and modelling the influence of household characteristics on per capita water consumption. Water Resources Management, 30(9), 2931-2955.

Willis, R. M., Stewart, R. A., Giurco, D. P., Talebpour, M. R., \& Mousavinejad, A. (2013). End use water consumption in households: impact of socio-demographic factors and efficient devices. Journal of Cleaner Production, 60, 107-115. 